\title{
PENGARUH TEMPERATUR DAN UKURAN PARTIKEL BIOMASSA TERHADAP BIO-OIL HASIL PIROLISIS AMPAS TEBU / BAGGASE
}

\author{
Ariany Zulkania \\ Jurusan Teknik Kimia, Fakultas Teknologi Industri, Universitas Islam Indonesia, \\ Jl.Kaliurang Km.14,5, Sleman, Yogyakarta, 55584 \\ E-mail:zulkania1@yahoo.com
}

\begin{abstract}
The bio-oil production from baggase using pyrolysis process was investigated in this study. A fixed bed reactor was utilized to investigate the effect of pyrolysis temperature and biomass particle size on the yield of bio-oil, tar, biochar and gas and properties of bio-oil. The pyrolysis temperature was ranging from 450 to $550^{\circ} \mathrm{C}$, while variations of particle size were $-20+30$ Mesh and $-30+40$ Mesh. The operation conditions of the pyrolysis were 15 minutes of resident time, $25^{\circ} \mathrm{C} /$ minute of heating ramp and $0.5 \mathrm{~L} / \mathrm{min}$ of $\mathrm{N}_{2}$ flowrate. Optimum conditions obtained for the maximum bio-oil yield $(28.11 \% \mathrm{wt})$ were $550^{\circ} \mathrm{C}$ and $-30+40$ Mesh of particle size. However, pyrolysis for $-20+30 \mathrm{Mesh}$ of biomass particle size had optimum temperature on $500^{\circ} \mathrm{C}$ which had $27.89 \%$ wt of bio-oil yield.

On the other hand, all bio-oils were characterized in detail by determining their density, viscosity, $\mathrm{pH}$, acetic acid content and heating value. Bio-oils produced have the following properties: density of 1.0667-1.0867 $\mathrm{gr} / \mathrm{ml}$, viscosity of 1.3034-1.7821 cP, pH of 2.3835-2.7865, acetic acid content of $0.4320-0.5600 \mathrm{mg} / \mathrm{ml}$ bio-oil, dan heating value of $9.3168-10.8173 \mathrm{MJ} / \mathrm{kg}$. The highest heating value is contented by bio-oil produced with $550^{\circ} \mathrm{C}$ of temperature pyrolysis and $-30+40$ Mesh of biomass particle size.
\end{abstract}

Keywords : Baggase, Pyrolysis, Bio-Oil, Heating Value.

\section{PENDAHULUAN}

\subsection{Latar Belakang}

Kebutuhan energi di dunia semakin hari semakin meningkat seiring pertumbuhan populasi manusia. Akan tetapi hal ini tidak diimbangi dengan peningkatan ketersediaan sumber energi yang sebagian besar masih dipenuhi dari bahan bakar fosil. Energi alternatif menjadi pilihan untuk pemenuhan ketersediaan energi tersebut. Pemerintah terus mengoptimalkan sumber - sumber energi alternatif sehingga ketahanan energi nasional dapat direalisasikan. Pengembangan sumber energi baru dan terbarukan (EBT) terus dioptimalkan untuk mengurangi ketergantungan terhadap sumber energi fosil. Prospek pemanfaatan EBT sangat besar dan beragam. Saat ini, berdasarkan Data Cadangan dan Produksi Energi Terbarukan Indonesia 2007, pemanfaatan EBT baru mencapai 5,921 MW (3,64\%) dari total potensi sebesar 162,2770 MW (ESDM, 2015).
Sumber energi baru dan terbarukan yang masih melimpah di Indonesia salah satunya adalah biomassa. Potensi biomassa di Indonesia mencapai 32,654 MW, sementara kapasitas terpasang adalah 1,1716 MW (ESDM, 2015). Dibandingkan dengan energi terbarukan lainnya, proses konversi energi biomassa terbilang lebih murah (The Japan Institute of Energy, 2008).

Biomassa sering diterjemahkan sebagai bioresources atau sumber daya yang diperoleh dari hayati. Basis sumber daya alam meliputi ribuan spesies tanaman daratan dan lautan, berbagai sumber pertanian, perhutanan, limbah residu dari proses industri, dan kotoran hewan (The Japan Institute of Energy, 2008). Biomassa merupakan sumber daya alam terbaharui dan energi yang diperoleh dari biomassa disebut energi terbarukan.

Biomassa dapat ditransfer menjadi bahan bakar berenergi tinggi dengan proses biochemical (fermentasi) atau 
thermochemical. Proses biochemical lebih selektif dan memerlukan waktu reaksi yang lama, tetapi tidak memerlukan energi dari luar yang sangat besar. Hal ini berbanding terbalik dengan proses thermochemical yang memerlukan energi luar yang besar tetapi waktu reaksi tidak lama. Produk yang dihasilkan dari proses thermochemical ini juga lebih beragam (Montoya, dkk., 2015; Basu, 2010). Beberapa proses thermochemical yang dikenal antara lain combustion, pyrolysis, gasification and liquefaction (Basu, 2010).

Dalam proses pirolisis, biomassa dipanaskan dalam kondisi bebas oksigen untuk menghasilkan bio-arang, bio-oil dan gas yang tak terembunkan, dimana hasilnya sangat bergantung pada kondisi operasinya. Beberapa parameter penting dalam proses pirolisis : Kecepatan pemanasan, temperatur akhir (suhu pirolisis) dan waktu tinggal dalam zona reaksi (Basu, 2010).

Salah satu energi alternatif hasil dari proses pirolisis adalah bio-oil atau asap cair dari biomassa, seperti tongkol jagung, kayu, kulit kayu atau biomassa lainnya yang mengandung selulosa yang dapat diolah menjadi energi alternatif dan limbah organik (Hambali, dkk., 2007; Wibowo, 2013 ; Sukarjo, dkk., 2014 ). Bio-oil mengandung karbon, hidrogen dan oksigen dengan sedikit kandungan sulfur. Komponen organik terbesar dalam bio-oil yaitu lignin, alkohol, asam organik, dan karbonil. Karakteristik tersebut menjadikan bio-oil sebagai bahan bakar yang ramah lingkungan. Bio-oil adalah bahan bakar cair bewarna gelap beraroma seperti asap dan memiliki nilai kalor (heating value) yang lebih besar dibandingkan bahan bakar oksigenasi lainnya (seperti metanol) dan nilainya hanya sedikit lebih rendah dibandingkan dengan minyak diesel dan minyak bahan bakar lainnya (Hambali, dkk, 2007).

Beberapa kajian pirolisis untuk menghasilkan bio-oil telah dilakukan. Sukarjo, dkk. (2014) meneliti pengaruh temperatur terhadap pirolisis serbuk gergaji. Temperatur divariasikan dari $200^{\circ} \mathrm{C}$ sampai $500^{\circ} \mathrm{C}$ dan menggunakan ukuran serbuk kayu random. Hasil kajiannya menunjukkan untuk rendemen bio-oil terbanyak terjadi pada temperature $400^{\circ} \mathrm{C}$ sebesar $29 \%$. Selain itu, kajian pengaruh temperatur terhadap hasil bio-oil dari proses pirolisis tempurung kelapa dan cangkang kopi juga dilakukan oleh Hidayat dan Qomaruddin (2015), dimana kenaikan temperatur dari $150^{\circ} \mathrm{C}$ sampai $250^{\circ} \mathrm{C}$ dapat menaikkan kapasitas asap cair/bio-oil sampai 56\% untuk tempurung kelapa dan 213\% untuk cangkah kopi. Hal ini menunjukkan bahwa kenaikan temperatur yang sesuai dapat menyebabkan pembakaran yang lebih sempurna sehingga hasil dapat naik secara signifikan.

Bio oil dari ampas tebu/baggase yang telah diteliti antara lain oleh Montoya, dkk. (2015) yang menggunakan baggase residu dari pabrik-pabrik gula di Colombia. Baggase berukuran $0,5125 \mathrm{~mm}$ dan 0,075 $\mathrm{mm}$ dipirolisis cepat dalam reactor fluidized bed dengan variasi temperatur $500^{\circ} \mathrm{C}$ dan 550 ${ }^{\circ} \mathrm{C}$, kecepatan gas 20-50 L/men, kecepatan umpan $2,0-5,3 \mathrm{~kg} / \mathrm{jam}$, dan penambahan zat inert dengan ukuran $0,2-0,512 \mathrm{~mm}$. Studi menunjukkan bahwa arang dan bio oil yang dihasilkan dari proses pada temperatur $500^{\circ} \mathrm{C}$ lebih tinggi dibanding yang $550^{\circ} \mathrm{C}$. Perbedaan ukuran partikel biomassa menunjukkan bahwa partikel dengan ukuran 0,075 mm menghasilkan bio oil lebih tinggi dan arang lebih rendah dibandingkan dengan partikel berukuran $0,5125 \mathrm{~mm}$.

Studi lain yang menggunakan ampas tebu sebagai biomassa dilakukan oleh Erawati, dkk (2013). Pirolisis ampas tebu menjadi bio oil dilakukan dalam reaktor pirolisis dengan kecepatan pemanasan yang divariasikan dari 100 Volt sampai 120 Volt dan variasi diameter biomassa dari -20-25 Mesh sampai -40 Mesh. Dari kajian menunjukkan bahwa yield bio-oil turun dari $40,32 \%$ pada diameter $-20+25$ Mesh menjadi $34,16 \%$ pada diameter partikel -40 mesh. Sedangkan semakin besar voltase kecepatan pemanasan (dari 100 Volt ke 120 Volt) yield dari bio oil semakin besar $(33,31 \%$ menjadi $36,10 \%)$. 
Proses pirolisi ampas tebu yang dibuat pelet dengan dicampur molase dilakukan oleh Goncalves dkk (2016). Pirolisis dilakukan dengan kecepatan pemanasan 14 ${ }^{\circ} \mathrm{C} /$ menit sampai temperatur $850^{\circ} \mathrm{C}$. Waktu tinggal pada temperatur pirolisis selama 1 jam. Kajian menunjukkan bahwa bio oil yang dihasilkan sebanyak 41,11\% dan gas sebesar $32,99 \%$.

Kajian ini ditujukan untuk melihat pengaruh temperatur dan ukuran partikel biomassa ampas tebu terhadap bio-oil hasil pirolisis pada reaktor fixed-bed. Variasi temperatur yang diambil $450^{\circ} \mathrm{C}, 500^{\circ} \mathrm{C}$ dan $550^{\circ} \mathrm{C}$. Sedangkan variasi ukuran partikelnya adalah $-20+30$ Mesh dan -30+40 Mesh.

\subsection{Tujuan Penelitian}

Tujuan dari penelitian ini adalah :

1. Mengetahui temperatur optimum, yang dapat menghasilkan rendemen bio-oil dari ampas tebu yang terbaik.

2. Mengetahui ukuran padatan biomassa yang paling sesuai untuk proses pirolisis agar menghasilkan nilai kalor bio-oil yang terbaik.

\subsection{Hipotesis}

1. Temperatur optimum pirolisis ampas tebu menjadi bio-oil berada di rentang temperature $450^{\circ} \mathrm{C}$ sampai $500^{\circ} \mathrm{C}$.

2. Ukuran partikel material biomassa berpengaruh pada yield / rendemen dan sifat bio-oil.

\section{METODE PENELITIAN}

\subsection{Bahan dan Alat}

Bahan baku dari limbah industri berupa ampas tebu yang didapat dari pabrik gula Madukismo Yogyakarta. Sedangkan alat alat yang akan digunakan yaitu grinder, reaktor fixed-bed dengan ukuran diameter 7,5 $\mathrm{cm}$ dan tinggi $23,5 \mathrm{~cm}$, furnace, termokopel, oven, timbangan analitik, tabung serta regulator gas $\mathrm{N} 2$, condenser, piknometer, viskometer Oswald, gelas piala, 1 set buret, Erlenmeyer, labu ukur, ayakan -20+30 Mesh dan -30+40 Mesh, stopwatch, $\mathrm{pH}$ meter dan
Bom-Calorimeter Gallenkamp. Rangkaian alat pirolisis dapat dilihat pada gambar 1 .

\subsection{Pelaksanaan Penelitian}

Proses pirolisis ampas tebu menjadi biooil akan dilakukan dengan beberapa tahap.

\subsubsection{Tahap Persiapan Biomassa}

Pada tahap ini, $\pm 2 \mathrm{~kg}$ ampas tebu dicuci terlebih dulu untuk menghilangkan kotoran. Kemudian ampas tebu dikeringkan dengan dijemur di bawah sinar matahari kurang lebih 1-2 hari (tidak ada hujan). Kemudian ampas tebu di-grinder untuk mendapat ukuran yang dikehendaki. Pengayakan dilakukan untuk ukuran -20+30 Mesh dan -30+40 Mesh. Proses pengeringan dilakukan dengan menggunakan oven pada temperatur $110^{\circ} \mathrm{C}$ selama 1 jam. Setelah itu biomassa siap untuk digunakan pada proses pirolisis.

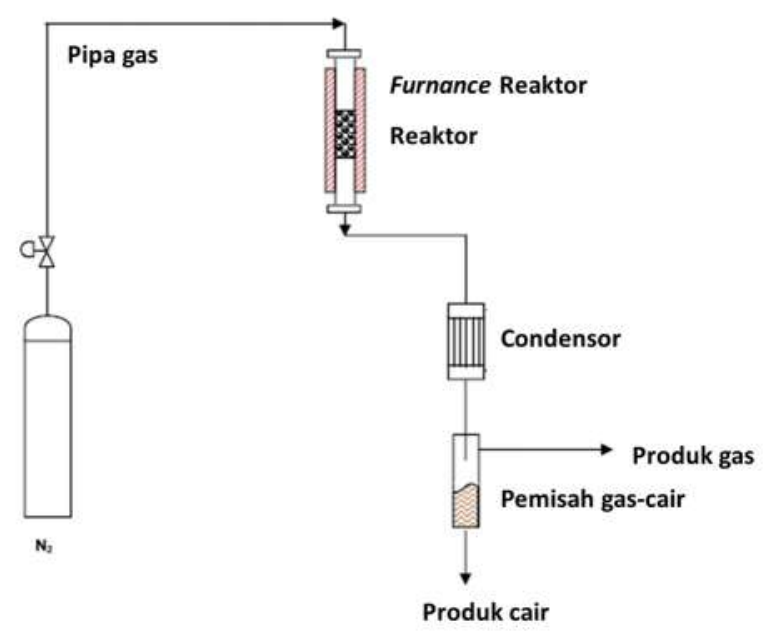

Gambar 1. Skema Rangkaian Alat Pirolisis (Modifikasi dari Rangkaian Alat Pirolisis Grag, dkk. (2016)).

\subsubsection{Proses Pirolisis Ampas Tebu Menjadi Bio-Oil}

Biomassa yaitu ampas tebu sebanyak 90 - 110 gram dimasukan kedalam reaktor fixed-bed. Reaktor dimasukkan ke dalam furnance yang berdiameter $20 \mathrm{~cm}$ dan tinggi $25 \mathrm{~cm}$. Suhu di dalam reaktor diukur dengan termokopel. Kemudian dilakukan proses pirolisis dengan menambahkan / menghubungkan gas nitrogen $0,5 \mathrm{~L} /$ menit ke reaktor. 
Reaktor dioperasikan pada temperatur 450,500 dan $550^{\circ} \mathrm{C}$, dengan 2 variasi ukuran partikel biomassa, yaitu $-20+30$ Mesh dan 30+40 Mesh. Kecepatan pemanasan sebesar $25^{\circ} \mathrm{C} /$ menit, dan waktu tinggal setelah temperatur pirolisis tercapai selama 15 menit. Proses pirolisis akan menghasilkan produk cair (bio-oil) akibat proses kondensasi, arang / char dan gas. Bio-oil yang didapat kemudian dianalisa sifat fisika seperti densitas, viskositas, $\mathrm{pH}$, kandungan asam asetat, dan nilai kalornya.

\subsubsection{Analisis Hasil}

Hasil produk pirolisis berupa bio-oil, tar, arang dan gas dihitung dengan persamaan sebagai berikut (Garg, dkk., 2016) :

Yiold bio oil $(\%)=\frac{\text { bio oil }(g n)}{\text { biomassa mosuk reaktor }(g r)} \times 100 \%$

Yield $\operatorname{tar}(\%)=\frac{\operatorname{tar}(g r)}{\text { biomassamasuk reaktor }(a r)} \times 100 \%$

Yield arang $(\%)=\frac{\operatorname{arang}(g r)}{\text { biomassamasuk reaktor }(g r)} \times 100 \%$

Yield gas $(\%)=1-Y_{\text {bio oil }}-Y_{\text {tar }}-Y_{\text {arang }}$
Penentuan kandungan asam asetat dengan cara titrasi bio-oil dengan menggunakan larutan $\mathrm{NaOH} 0,1 \mathrm{~N}$. Adapun perhitungan kandungan asam asetat $(\mathrm{mg} / \mathrm{ml})$ adalah sebagai berikut :

\section{ml titrasi $x$ N NaOH $x$ BM Asam asetat}

$$
\text { volume as ap cair }(\mathrm{ml})
$$

Dimana :

$\mathrm{ml}$ titrasi : volume $\mathrm{NaOH}$ yang terpakai.

$\mathrm{N} \mathrm{NaOH}$ : Normalitas larutan $(0,1 \mathrm{~N})$.

BM Asam Asetat : $60 \mathrm{gr} / \mathrm{mol}$.

Nilai kalor diukur dengan bomCalorimeter Gallenkamp SG92/03/006 di laboratorium Perpindahan Massa dan Perpindahanan Massa PAU UGM.

\section{HASIL DAN PEMBAHASAN}

Pirolisis biomassa ampas tebu dilakukan pada tiga variasi temperatur, yaitu 450, 500 dan $550^{\circ} \mathrm{C}$, untuk masing-masing ukuran partikel biomassa. Sedang variasi ukuran partikel adalah $-20+30$ Mesh dan $-30+40$ Mesh. Tabel 1 menunjukkan hasil penimbangan dan perhitungan produkproduk hasil pirolisis.

Hasil dari proses pirolisis ada 3 tipe yaitu ; padatan (arang / biochar), cairan dan gas. Dua fraksi cairan yang didapat dari proses penyaringan cairannya adalah fraksi yang larut dalam air (bio-oil) dan fraksi yang tidak larut dalam air (tar) (Bertero, dkk., 2014).

Tabel 1. Rendemen / yield Hasil Pirolisis Biomassa Ampas Tebu

\begin{tabular}{|c|c|c|c|c|}
\hline \multirow[b]{2}{*}{ Produk } & \multirow{2}{*}{$\begin{array}{c}\text { Ukuran partikel } \\
(\text { Mesh })\end{array}$} & \multicolumn{3}{|c|}{ Temperatur $\left({ }^{\circ} \mathrm{C}\right)$} \\
\hline & & 450 & 500 & 550 \\
\hline \multirow{2}{*}{$\begin{array}{l}\text { Bio-oil } \\
\text { (\% brt) }\end{array}$} & $-20+30$ & 23,636 & 27,889 & 27,111 \\
\hline & $-30+40$ & 25,091 & 26,500 & 28,111 \\
\hline \multirow{2}{*}{$\begin{array}{l}\text { Tar } \\
(\% \text { brt })\end{array}$} & $-20+30$ & 2,818 & 2,444 & 2,889 \\
\hline & $-30+40$ & 3,273 & 3,200 & 3,444 \\
\hline \multirow{2}{*}{$\begin{array}{l}\text { Arang } \\
(\% \text { brt })\end{array}$} & $-20+30$ & 30,273 & 32,111 & 27,222 \\
\hline & $-30+40$ & 29,182 & 28,900 & 27,222 \\
\hline \multirow{2}{*}{$\begin{array}{l}\text { Gas } \\
(\% \text { brt })\end{array}$} & $-20+30$ & 43,273 & 37,556 & 42,778 \\
\hline & $-30+40$ & 42,454 & 41,400 & 41,222 \\
\hline
\end{tabular}


Yield bio-oil terbesar dihasilkan pada temperatur $550^{\circ} \mathrm{C}$ dengan ukuran partikel biomassa $-30+40$ Mesh, yaitu sebesar $28,111 \%$. Sedangkan hasil yang terkecil pada temperatur $450^{\circ} \mathrm{C}$ dan ukuran partikel 20+30 Mesh sebesar 23,636\%.

\subsection{Pengaruh Temperatur Terhadap} Yield Bio-oil

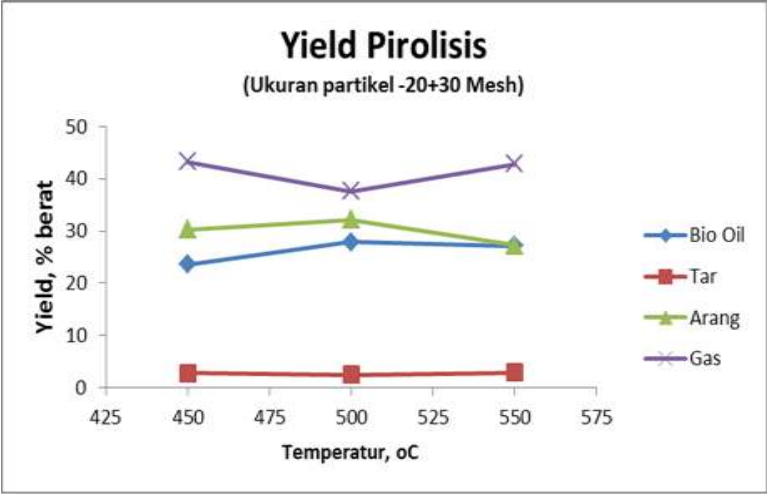

Gambar 2. Efek Temperatur Pada Hasil Pirolisis untuk Ukuran Partikel Biomassa 20+30 Mesh (Uk 1).

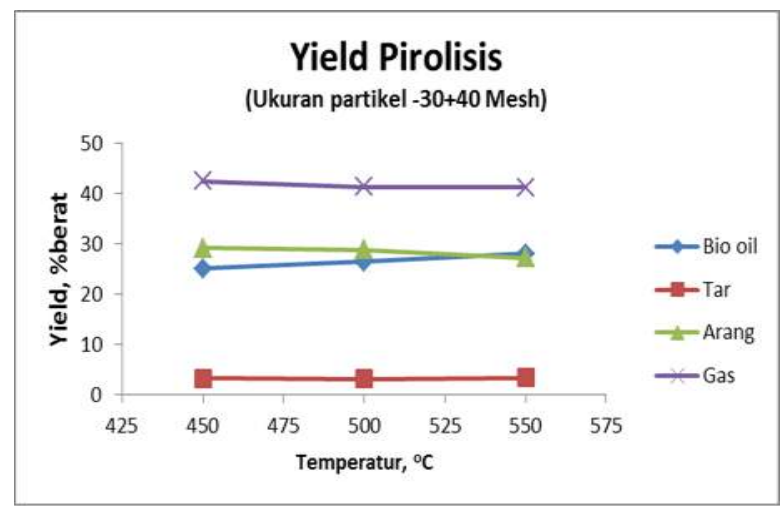

Gambar 3. Efek Temperatur Pada Hasil Pirolisis Untuk Ukuran Partikel Biomassa 30+40 Mesh (Uk 2).

Pengaruh temperatur terhadap hasil pirolisis dapat dilihat pada gambar 2 dan 3, dimana yield dari bio-oil, tar, dan arang didapat dengan cara menimbang dan kemudian dihitung dengan persamaan (1) sampai (3), sedangkan yield gas dihitung dengan persamaan (4) yang merupakan hasil selisih dari 3 produk yang lain.
Yield bio-oil untuk ukuran partikel biomassa $-20+30$ Mesh bervariasi dari $23,636 \%$ sampai $27,889 \%$. Seperti terlihat pada gambar 2, temperatur optimum untuk mendapatkan bio-oil terbanyak pada ukuran ini adalah pada $500^{\circ} \mathrm{C}$.

Begitu pula dengan arang yang dihasilkan terbanyak pada $500^{\circ} \mathrm{C}$. Tar relatif sama pada ketiga temperatur. Sedangkan gas menunjukkan bahwa pada temperatur $500^{\circ} \mathrm{C}$ terjadi hasil yang paling sedikit dibandingkan pada temperatur $450^{\circ} \mathrm{C}$ dan $550^{\circ} \mathrm{C}$. Perbedaan hasil bio-oil pada temperatur $450^{\circ} \mathrm{C}$ dan $500^{\circ} \mathrm{C}$ karena meningkatnya reaksi devolatilisasi pada temperatur yang lebih tinggi karena energi tersedia lebih banyak dan hal ini menyebabkan terputusnya ikatan dalam senyawa organik sehingga meningkat hasil cairannya. Temperatur $500^{\circ} \mathrm{C}$ ini menjadi kondisi dimana hasil bio-oil yang terbanyak. Di atas temperatur ini, bio-oil dan arang berkurang sedang hasil gas meningkat karena terjadi reaksi cracking sekunder dari uap pirolisis dan kemungkinan terjadi dekomposisi sekunder arang.

Fenomena yang berbeda terlihat pada hasil pirolisis biomassa yang berukuran 30+40 Mesh. Dari gambar 2 terlihat bahwa yield bio-oil cenderung masih terus meningkat pada temperatur $550^{\circ} \mathrm{C}$. Dengan menaikkan temperatur pirolisis di atas $550^{\circ} \mathrm{C}$ dapat terlihat temperatur optimum pirolisis untuk menghasilkan bio-oil yang terbanyak. Sedangkan yield arang dan gas cenderung sedikit menurun terus dari temperatur $450^{\circ} \mathrm{C}$ sampai $550^{\circ} \mathrm{C}$. Pada ukuran partikel biomassa yang lebih kecil ini, kenaikan temperatur menyebabkan reaksi devolatilisasi yang terus menerus dengan kenaikkan temperatur dan pada temperatur yang lebih tinggi karena energi tersedia lebih banyak menyebabkan terputusnya ikatan dalam senyawa organik. 


\subsection{Pengaruh Ukuran Partikel Biomassa Terhadap Yield Bio-oil}

Variasi dua ukuran partikel biomassa dilakukan pada tiga tempertur.

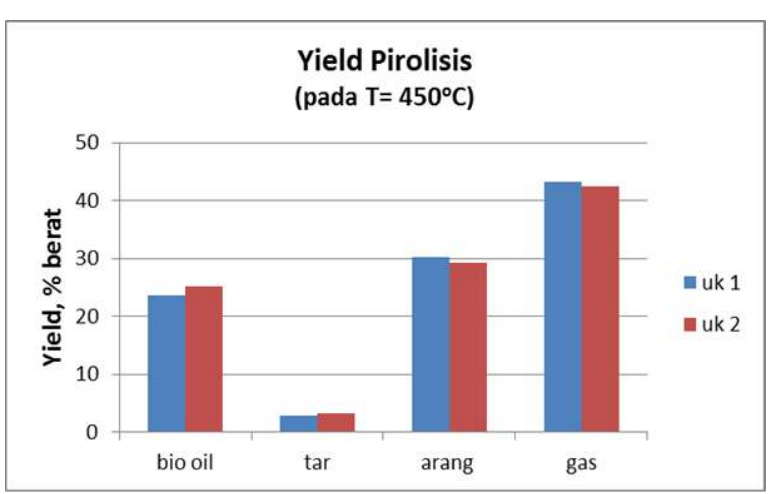

Gambar 4. Efek Ukuran Partikel Biomassa Pada Temperatur $450^{\circ} \mathrm{C}$

$($ Uk 1 $=-20+30$ Mesh; Uk 2= -30+40 Mesh).

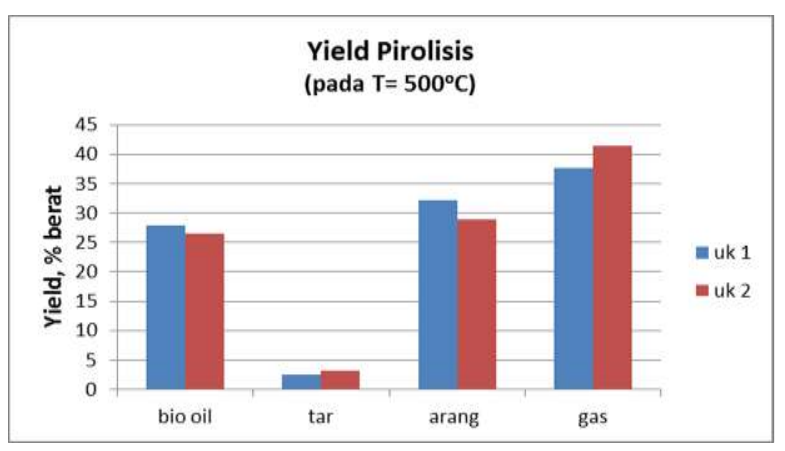

Gambar 5. Efek Ukuran Partikel Biomassa Pada Temperatur $500^{\circ} \mathrm{C}$

$(\mathrm{Uk} 1=-20+30 \mathrm{Mesh}$; Uk 2= $-30+40 \mathrm{Mesh})$

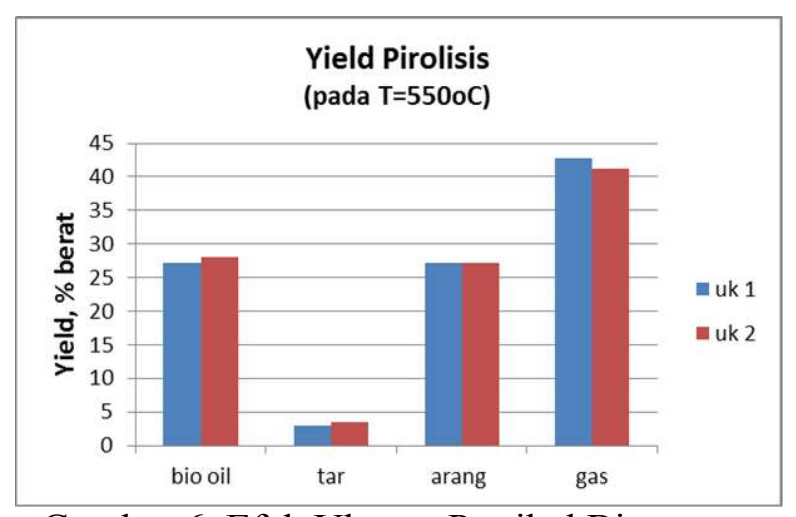

Gambar 6. Efek Ukuran Partikel Biomassa Pada Temperatur $550^{\circ} \mathrm{C}$

$($ Uk 1 $=-20+30$ Mesh; Uk 2= $-30+40$ Mesh).

Dari gambar 4, 5 dan 6 terlihat bahwa pada temperatur $500^{\circ} \mathrm{C}$, ukuran partikel biomassa yang lebih besar (uk 1, -20+30 Mesh) akan memberikan yield bio-oil lebih besar daripada ukuran partikel dibawahnya (30+40 Mesh). Tetapi pada temperatur di bawah dan di atas $500^{\circ} \mathrm{C}$, ukuran partikel biomassa yang lebih kecil akan menghasilkan yield bio-oil yang lebih besar.

\subsection{Karakteristik Produk Bio-Oil}

Tabel 2 menunjukkan beberapa sifat dari produk bio-oil.

Tabel 2. Karakteristik Bio-Oil dari

Ampas Tebu

\begin{tabular}{ccccc}
\hline \multirow{2}{*}{ Parameter } & Ukuran Partikel & \multicolumn{3}{c}{ Temperatur (oC) } \\
\cline { 3 - 5 } & $($ Mesh) & $\mathbf{4 5 0}$ & $\mathbf{5 0 0}$ & $\mathbf{5 5 0}$ \\
\hline Densitas & $(-20+30)$ & 1,0867 & 1,0667 & 1,0867 \\
(gr/ml) & $(-30+40)$ & 1,0800 & 1,0767 & 1,0700 \\
\hline Viskositas & $(-20+30)$ & 1,6773 & 1,3034 & 1,7821 \\
$(\mathrm{cP})$ & $(-30+40)$ & 1,4673 & 1,4282 & 1,5139 \\
\hline $\mathrm{pH}$ & $(-20+30)$ & 2,7865 & 2,7040 & 2,3835 \\
& $(-30+40)$ & 2,4735 & 2,5875 & 2,4925 \\
\hline Asam Asetat & $(-20+30)$ & 0,4860 & 0,4320 & 0,5600 \\
$(\mathrm{mg} / \mathrm{ml})$ & $(-30+40)$ & 0,5300 & 0,5200 & 0,5060 \\
\hline Nilai kalor & $(-20+30)$ & 9,3168 & 10,0958 & 10,4203 \\
$(\mathrm{MJ} / \mathrm{kg})$ & $(-30+40)$ & 9,7162 & 10,2729 & 10,8173 \\
\hline & & & &
\end{tabular}

Densitas merupakan sifat fisis penting yang berhubungan dengan proses transportasi. Hasil pengujian berat jenis / densitas bio-oil yang dihasilkan pada tiga variasi temperatur dan dua variasi ukuran partikel biomassa berkisar antara 1,0667 sampai 1,0887 gr/ml. Hasil ini lebih rendah dari densitas bio-oil hasil pirolisis kayu 
sengon yang berkisar antara 1,098-1,166 $\mathrm{gr} / \mathrm{ml}$ pada temperatur pirolisis $550-600^{\circ} \mathrm{C}$ dan ukuran partikel 20, 40 dan 60 Mesh (Wibowo dan Hendra, 2015). Tetapi sedikit lebih tinggi dari densitas bio-oil hasil pirolisis ampas tebu dengan ukuran bervariai dari $-20+25$ Mesh sampai -40 dan dimana densitas berkisar antara 1,03-1,50 gr/ml (Erawati, 2013).

Tingginya berat jenis bio-oil dipengaruhi oleh banyaknya senyawa dalam bio-oil yang memiliki berat molekul tinggi. Densitas untuk bio-oil dari partikel berukuran lebih besar $(-20+30$ Mesh), menunjukkan yang terkecil pada suhu $500^{\circ} \mathrm{C}$. Hal ini terjadi pada suhu optimum untuk mendapatkan rendemen bio-oil yang terbesar (Tabel 1 dan Gambar 2). Sedangkan bio-oil dari partikel biomassa berukuran lebih kecil (-30+40 Mesh), menunjukkan densitas yang terus mengecil dengan naiknya temperatur. Hal ini sejalan dari kecenderungan rendemen bio-oil-nya, dimana dengan naiknya temperatur dari $450^{\circ} \mathrm{C}$ sampai $550^{\circ} \mathrm{C}$, rendemen bio-oil masih terus meningkat.

Viskositas dari bio-oil yang diuji memiliki kisaran nilai $1,3034 \mathrm{cP}$ sampai $1,7821 \mathrm{cP}$. Viskositas tertinggi terjadi pada temperatur $550^{\circ} \mathrm{C}$ dengan ukuran partikel biomassa -20-30 Mesh. Sedangkan viskositas terendah terjadi pada pirolisis pada temperatur $500^{\circ} \mathrm{C}$ dengan ukuran partikel biomassa $-20+30$ Mesh.

Bio-oil dari ampas tebu hasil kajian memiliki nilai $\mathrm{pH}$ berkisar dari 2,3835 sampai 2,7865, $\mathrm{pH}$ tetinggi didapat pada saat temperatur $450^{\circ} \mathrm{C}$ dan ukuran partikel 20+30 Mesh, sedangkan $\mathrm{pH}$ terendah didapat pada temperatur $550^{\circ} \mathrm{C}$ dan ukuran partikel $20+30$ Mesh. Keasaman yang tinggi disebabkan adanya asam asetat dan asam lainnya akibat proses pirolisis yang memecah selulosa dan lignin serta zat ekstraktif yang bersifat asam. Nilai $\mathrm{pH}$ hasil pengujian sesuai pendapat Easterly (2002) bahwa keasaman bio-oil cukup tinggi yaitu antara 2,5-3,0 dan mensyaratkan penanganan penyimpanan bio-oil menggunakan bahan yang tahan karat, seperti stainless steel, gelas kaca, plastik, dan fiberglass.

Keasaman yang tinggi membuat bio-oil hanya dapat digunakan sebagai bahan bakar langsung seperti boiler, penggunaan untuk mesin tidak disarankan karena dapat menyebabkan mesin berkarat akibat kandungan asam yang tinggi. Untuk dapat digunakan sebagai bahan bakar mesin, harus dilakukan upgrading dengan beberapa alternative cara seperti dikaji oleh Xiu dan Shahbazi (2012) antara lain hydrotreating, hydro cracking, steam reforming dan lain lain, dimana senyawa dengan berat molekul tinggi akan terpecah menjadi senyawa alkana.

Kandungan asam yang tinggi dapat terlihat dari tabel 2 dan gambar 7, dimana bio-oil yang dihasilkan dari pengujian memiliki kisaran kandungan asam asetat sebesar $0,4320 \mathrm{mg} / \mathrm{ml}-0,5600 \mathrm{mg} / \mathrm{ml}$. Kandungan asam asetat dalam bio-oil tergantung pada bahan biomassanya, umumnya kandungan antara $15-59 \%$ berat (Bertero, dkk., 2014). Beberapa bio-oil menunjukkan bahwa kandungan asam asetatnya tinggi (Bertero, dkk., 2014; Xiujuan, dkk., 2011).

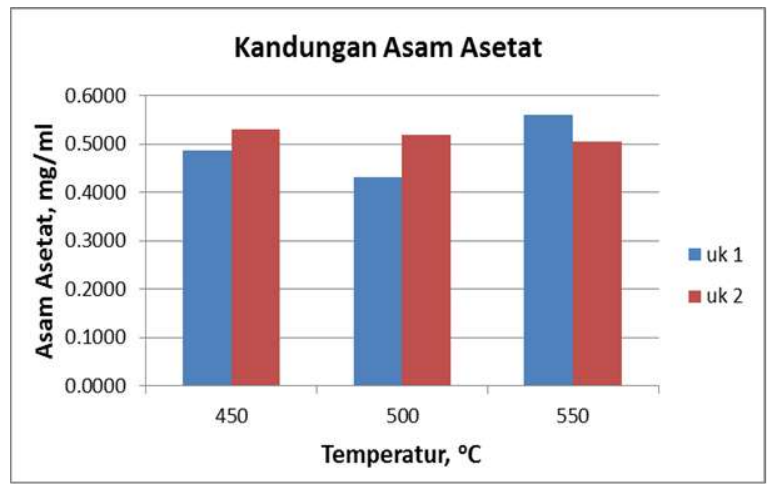

Gambar 7. Efek Temperatur dan Ukuran Partikel Pada Kandungan Asam Asetat Bio-Oil

(uk 1: $-20+30$ Mesh; uk 2: $-30+40$ Mesh)

Dengan naiknya temperatur pada partikel ukuran $-30+40$ Mesh, kandungan asam asetat cenderung turun. Sedangkan pada ukuran partikel yang lebih besar ($20+30$ Mesh), pada temperature $500^{\circ} \mathrm{C}$ kandungan asam asetat adalah yang terkecil, 
dimana naik kembali ketika temperatur pirolisis naik.

Nilai kalor pembakaran menunjukkan energi kalor yang dikandung dalam tiap satuan massa bahan bakar. Nilai kalor bio-oil naik dengan meningkatnya temperatur pada kedua ukuran partikel biomassa. Hal ini disebabkan dengan naiknya temperatur pirolisis maka kandungan oksigen dan air dalam bio-oil cenderung akan semakin berkurang sehingga meningkatkan nilai kalor.

Dari ukuran partikel biomassa, terlihat bahwa bio-oil dari partikel dengan ukuran yang lebih kecil (Uk 2) memiliki nilai kalor yang lebih tinggi daripada Uk 2. Dengan ukuran diameter partikel lebih kecil, maka luas permukaan total dari partikel relatif akan lebih besar yang dapat menyebabkan air dan oksigen relatif lebih banyak teruapkan/terlepas dari permukaan partikel pada saat proses pirolisis.

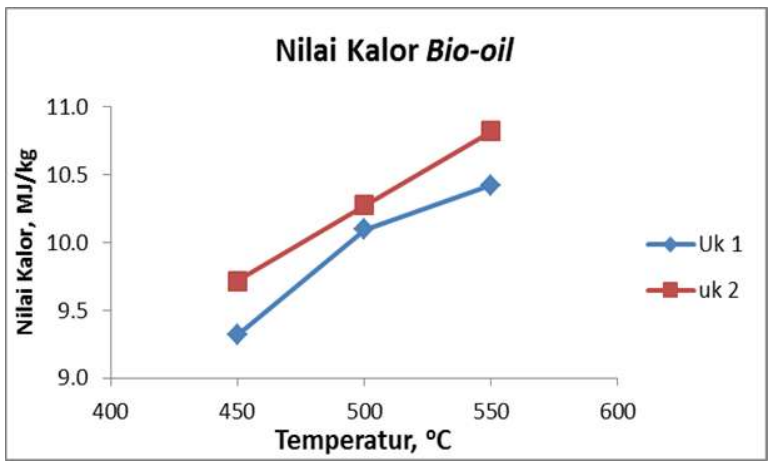

Gambar 8. Pengaruh Temperatur dan Ukuran Partikel Pada Nilai Kalor Bio-Oil

(uk 1: -20+30 Mesh; uk 2: -30+40 Mesh).

\section{KESIMPULAN DAN SARAN \\ 4.1. Kesimpulan}

Proses pirolisis ampas tebu dilakukan dalam reaktor fixed-bed dengan ukuran diameter $7,5 \mathrm{~cm}$ dan tinggi $23,5 \mathrm{~cm}$, yang ditempatkan dalam furnace, dengan tiga variasi temperatur $\left(450,500\right.$, dan $\left.550^{\circ} \mathrm{C}\right)$ dan dua variasi ukuran partikel biomassa $(-20+30$ Mesh dan -30+40 Mesh). Rendemen bio-oil terbesar terjadi pada temperatur $550^{\circ} \mathrm{C}$ untuk partikel biomassa berukuran $-30+40 \mathrm{Mesh}$.
Temperatur pirolisis optimum pada kedua ukuran partikel biomassa menunjukkan kecendungan yang berbeda. Pada $-20+30$ Mesh, temperatur optimum pirolisis terjadi pada $500^{\circ} \mathrm{C}$, sedangkan untuk ukuran partikel biomassa yang lebih kecil $(-30+40$ Mesh) temperatur optimum masih dimungkinkan di atas $550^{\circ} \mathrm{C}$.

Sifat bio-oil yang dihasilkan menunjukkan nilai densitas berkisar 1,0667$1,0867 \mathrm{gr} / \mathrm{ml}$, nilai viskositas berkisar 1,3034-1,7821 cP, nilai $\mathrm{pH}$ berkisar 2,38352,7865, kandungan asam asetat berkisar 0,4320-0,5600 $\mathrm{mg} / \mathrm{ml}$ bio-oil, dan nilai kalor berkisar 9,3168-10,8173 MJ/kg.

Nilai kalor pada kedua ukuran partikel biomassa menunjukkan hal yang sama yaitu akan naik dengan meningkatnya temperatur pirolisis.

\subsection{Saran}

Untuk penelitian selanjutnya diharapkan

Bahan baku biomassa dikeringkan dalam oven dengan waktu yang lebih lama (5-8 jam) untuk menghilangkan kandungan air sebanyak mungkin, sehingga cairan hasil pirolisis akan mengandung air lebih rendah dan berimbas kepada nilai kalor yang lebih tinggi.

Dilakukan karakterisasi terhadap kandungan kimia dari bio-oil yang dihasilkan.

\section{DAFTAR PUSTAKA}

Basu, P, "Biomass Gasification and Pyrolysis-Practical Design and Theory", Elsevier, Burlington MA, 2010.

Bertero, M., Gorostegui, H.A., Orrabalis, C.J., Guzman, C.A., and Calandri, E.L, "Characterization of The Liquid in The Pyrolysis of Residual Chanar and palm Fuit Biomasses", Fuel, Vol. 116, pp. 409-414, 2014. 
Easterly J.L, "Assessment of Bio-oil as A Replacement for Heating Oil", CONEG Policy Research Centre, Inc, 2002.

Erawati, E, Sediawan, W.B, dan Mulyono, P, "Karakteristik Bio-Oil Hasil Pirolisis Ampas Tebu (Baggase)", Jurnal Kimia Terapan Indonesia, Vol. 15, 2, pp. 4755, 2013.

ESDM, "Terkait Peningkatan Pengembangan dan Pemanfaatan EBT, Pemerintah Bentuk Ditjen Baru", diakses pada tanggal 9 September 2016 dari http://esdm.go.id/berita/323

- energi - baru - dan - terbarukan/3678

- terkait - peningkatan - pengembangan

- dan - pemanfaatan - ebt - pemerintah

- bentuk - ditjen - baru.html, 2015.

Garg, R, Anand, N., and Kumar, D, "Pyrolysis of Babool Seeds (Acacia nilotica) in A Fixed-Bed Reactor and Bio-oil Characterization", Renewable Energy, vol. 96, pp.167-171, 2016.

Goncalves, G.C., Pereira, N.C., and Veit, M.T, "Production of Bio Oil and Activated Carbon from Surgarcane Baggase and Mollases", Biomassa and Bioenergy, Vol. 85, pp.178-186, 2016.

Hambali, E., Mujdalipah, S., Tambunan, A.H., Pattiwiri, A.W., Hendroko, R, "Teknologi Bioenergi", Jakarta: Penerbit Agromedia Pustaka, 2007.

Hidayat, T. Dan Qomaruddin, "Analisa Pengaruh Temperatur Pirolisis dan Bahan Biomassa Terhadap Kapasitas Hasil pada Alat Pembuat Asap Cair", Prosiding Seminar Nasional Sains dan Teknologi ke-6 di Universitas Wahid Hasyim, Jombang, 2015.

Montoya J.I., Valdes, C., Chejne, F., Gomez, C.A., Blanco, A., Marrugo, G., Osorio, J., Castillo, E., Aristobulo, J., and Acero, J, "Bio-Oil Production from Colombia Baggase by Fast Pyrolysis in a Fluidized Bed: an Experimental Study", Journal of Analytical and Applied Pyrolysis, Vol. 112, pp. 379387, 2015.
Sukarjo, H., Cahyono M.S., dan Wardoyo, "Influence of Temperature to Bio-Oil Yield from Organic Waste Pyrolysis Process", Prosiding Seminar Nasional Aplikasi Sains \& Teknologi (SNAST), Yogyakarta, 2014.

The Japan Institute of Energy, "Buku Panduan Biomassa Asia: Paduan untuk Produksi dan Pemanfaatan Biomassa", Jepang, 2009.

Xiu, S. dan Shahbazi, A, "Bio-oil Production and Upgrading Research: A Review", Renewable and Sustainable Energy Review, Vol. 16, pp. 4406-4414, 2012.

Xiujuan, G., Shurong, W., Qi, W., Zuogang G., and Zhonyang, L, "Properties of Bio-oil from Fast Pyrolysis of Rice Husk", Chinese Journal of Chemical Engineering, Vol. 19, 1, pp. 116-121, 2011.

Wibowo, S., "Karaketristik Bio-oil Serbuk Gergaji Sengon (Paraserianthes Falcatariak L. Nielsen) Menggunakan Proses Pirolisis Lambat", Jurnal Penelitian Hasil Hutan, Vol. 31, 4, pp. 258-270, 2013.

Wibowo, S. dan Hendra, D, "Karakteristik Bio Oil dari Rumput Gelagah (Saccharum Spontaneum Linn.) Menggunakan Proses Pirolisis Cepat", Jurnal Penelitian Hasil Hutan, Vol. 3, 44, pp. 347-363, 2015. 